\title{
Family Communication Model in Establishing Understanding of Media Literacy
}

\author{
Mas'Amah", a) Ferly Tanggu Hana ${ }^{2)}$ \\ ${ }^{1}$ Universitas Nusa Cendana, Indonesia \\ ${ }^{2}$ Universitas Nusa Cendana, Indonesia \\ a) author correspondence : masamah1979@yahoo.com
}

DOI: https://doi.org/10.18196/jkm.112024

Article Info

Article history:

Received 25 Jul 2019

Revised 14 Oct 2019

Accepted 13 Nov 2019

\begin{abstract}
The research aims to find the communication behavior of Posyandu's (Indonesian maternal and child health service) attendants in establishing understanding of media literacy, the challenges they should face, including the solutios, as well as the family communication model. The research is vital since, in addition to a notion that effective media literacy started from a family, the attendants have been educated with various topics by various institution, including media literacy, making them suitable to be the representation of informative family and society's fine example. The research is a qualitative reseach using a case-study as the method. The informants are Posyandu's attendants, their family members, public figures, and the leader of KPID NTT that are determined with a purposive sampling. The data colections method used are interview, observation, and documentation while the data analysis are data reduction, data display, drawing and verifying conclusion, analyzing the data, and making summary. The finding demonstrate that Posyandu's attendant restrict family television time limit and internet use to raise understanding toward media literacy. Inconsistency in applying the rules and parents's difficulty in using the internet outright are the challenges that are dealth with. The attendants redirect the family members to assist them in doing chores and limit funding for purchasing internet data to tackle the problem.
\end{abstract}

Keywords: behavior; family communication; media literacy; posyandu cadres.

\section{ABSTRAK}

Penelitian ini bertujuan untuk mengetahui perilaku komunikasi kader Posyandu dalam membangun pemahaman literasi media, kendala yang dihadapi dan cara mengatasinya serta model komunikasi keluarga dalam membangun pemahaman literasi media. Penelitian ini penting karena literasi media yang efektif dimulai dari dalam keluarga, termasuk keluarga para kader Posyandu. Keluarga mereka dipandang tepat sebagai representasi keluarga yang informatif karena mereka kerap dibekali dengan berbagai informasi dari banyak lembaga, termasuk tentang literasi media, sehingga bisa menjadi teladan bagi masyarakat setempat. Jenis penelitian ini adalah kualitatif dengan metode studi kasus. Informan penelitian adalah kader Posyandu, anggota keluarga dari kader Posyandu, tokoh masyarakat dan ketua KPID NTT yang ditentukan dengan teknik purposive sampling. Teknik pengumpulan data wawancara, pengamatan, dokumentasi. Teknik analisis data yaitu reduksi data, menyajikan data, mengambil kesimpulan dan verifikasi, menganalisis data dan membuat lembar rangkuman. Hasil penelitian menunjukkan bahwa perilaku komunikasi kader Posyandu dalam membangun pemahaman literasi media dalam keluarga yaitu dengan melakukan pembatasan jam menonton televisi dan membatasi anggota keluarganya untuk mengakses internet. Kendala yang dihadapi dalam membangun pemahaman literasi media adalah orang tua tidak konsisten menerapkan aturan bermedia dan keterbatasan kemampuan orang tua dalam menggunakan internet. Sedangkan cara mengatasinya dengan mengajak 
anggota keluarganya membantu pekerjaan rumah dan membatasi dana yang diberikan untuk membeli paket internet.

Kata Kunci: Perilaku; Komunikasi Keluarga; literasi media; Kader Posyandu.

\section{INTRODUCTION}

Mass media is media that has become a communication channel in the process of mass communication. Recently, mass media is a challenge that cannot be skirted anymore, notably after mass media has been an inexorable part of modern society and has fused themselves with commonplace activities. Mass media almost cater for all human needs, ranging from entertainment, information, escapism, solution, to identities. Indeed, coupled with the advent of advanced technology, media can be an effective means to attain any objectives (Croteau: 2000). Mass media domination in modern society seems undeniable.

However, although current mass media, including television, radio, newspapers, magazines, books, movies, and the internet, has experienced significant development, whether in terms of technology or information, the growth also bears not only positive effects but also negative ones to the audiences. Ngafifi (2014) argued that technological development could negatively affect sociocultural aspects of society by, for example, provoking moral degradation, juvenile delinquency, and changes in human interaction patterns. Furthermore, Strasburger (2010) found a positive correlation between television programs and some negative consequences in American adolescents. For example, violent shows in television often stimulated overanxiety, sexual contents induce deviant sexuality, and advertisements engender consumerism because the teenagers tried to imitate celebrities' hairstyles and fashion.

In light of that, media literacy that is widely known in Indonesia as Melek media become crucial for each media spectators. This concept persuades individuals to actively interpret messages transmitted by the media so that the individuals could be more critical during media use. According to Potter (Potter, 2004), media literacy is the active skills used by audiences to interpret messages that they face. Similarly, the National Leadership Conference on Media Education in the USA in 1992 defined media literacy as the ability to access, analyze, evaluate, and communicate the message in any form (Hobbs, 1999: 3).

Concern for the importance of media literacy has been conducted by many stakeholders, including the government and education institutions, and most of them agree that a current issue that needs to be addressed seriously is parents awareness on the importance of regulating their family members, particularly children, and adolescents to use media properly, as well as of creating healthy media use. Failing that ability, the optimal result will be hard to obtain.

Parents' involvements in realizing media literacy in families are vital. This is because, in the family, parents are the party that has deciding factors on media use. For instance, mostly, it is the parents that determine whether their families subscribe to a television cable or not, install internet access facilities or not, and provide a cell phone to the kids or not. It is also parents that set television watch-time in the family and limit and regulate devices that connect to internet services.

In many cases, when a kid is started to get afflicted by media's negative influences, such as reproducing swearing words, conducting aggressive behaviors, or being unsociable, parents tend to criticize media as the culprit that provokes their offsprings. They forget that it also occurs because of a lack of monitoring and supervision from the parents. Media management is required to guide the children to use media, especially in terms of responsibility and time-use (Adebiyi et al. 2015). Parents' understanding of media literacy, therefore, will not only have children and teenagers be more capable of regulating their media diet but also have parents be capable of interacting with media wisely. Starting from the family, hopefully, society could have social immunity from changes in socio-cultural aspects induced by mass media.

Oeltua village, which is located in Taebenu district, Kupang regency, is a region that contiguously borders Kupang city so that the society also receives a reasonably high number of 
mass media distributions. A study conducted by KPID NTT in 2011 showed that $81 \%$ of adolescents aged 10-15 years old watched television on a daily basis with entertainment and television series as the most popular channel, $67 \%$ access internet, $32 \%$ read textbook, non-fiction book, newspaper, and magazine, and $31 \%$ listened to radio, especially music and entertainment (Johdi, 2011). On the other hand, Mas' Amah (2017) found that mid-schoolers in Kupang city aged 10-15 years old watched television daily with entertainment channels as the most favorite program. They spent 4 to 5 hours a day to watch TV. A new data from KPID NTT (2019) even demonstrated that $73,19 \%$ of adolescents in NTT access internet and $26 \&$ of them spend 6 hours per day to do this activity. In light of that, it is reasonable to affirm that parental role in guiding and directing their family members in using media wisely becomes necessary.

Parents in Oeltua that are also Posyandu (Indonesian maternal and child health service) attendants own strategic roles in establishing a proper understanding of media literacy to children and adolescents. This is because Posyandu's attendants involve in various social events that enable them to acquire a vast insight, including insight on media literacy. Currently, six Posyandu have been established in some neighboorhood, and since each Posyandu employs five attendants, there are thirty attendants in Oeltea. Involving Posyandu attendants as one of the agents and channels to spread understanding of media literacy is deemed sufficient in manifesting media-literacyconscious family and social immunity.

The conditions engender the researchers to conduct research on the family communication model in establishing an understanding of media literacy and propose a research question on how the family communication model of Posyandu attendants figure in developing an understanding of media literacy in the family. This research, therefore, aims to comprehend the communication behavior of Posyandu attendants in establishing an understanding of media literacy, challenges that they should face, as well as the solution, and family communication model in constructing media literacy's knowledge. This research is expected to produce a family communication model of Posyandu attendants in raising understanding of media literacy in the family. Another benefit from this research is that it can be a material for, in general, policymakers, and, in particular, all social components in Kupang regency, to take action regarding media literacy in Kupang regency.

\section{METHOD}

This research was qualitative research that used a case-study as the method. The research was conducted in Oeltua village, Taebenu district, Kupan regency, EastNusa Tenggara province and the informants of the research were decided using purposive sampling, or selecting informants using specific considerations (Siregar, 2013: 60). Five Posyandu attendants, five representations of Posyandu attendant's family, one public figure, and one commissioner from KPID NTT were selected as the informants. Data collection was carried out by some techniques, namely interviews, observations, and documentation, while the data analysis technique used was Miles and Huberan interactive mode, consisting of data reduction, data display, and conclusion drawing (Miles dan Huberman, 1994: 58).

\section{RESULT AND DISCUSSION}

\section{Communication behavior of Posyandu attendants in raising understanding of media literacy in the family}

Behavior communication is a communicative action or behavior, whether verbal or nonverbal, executed by an individual. In other words, any individual work or response in a specific communicative environment or situation can be defined as behavior communication (Buluamang, 2018). With this in mind, informants' response in raising awareness of media literacy in the family can also be seen as behavior communication.

For communication technology seems difficult to bar and many contents in the media spread negative consequence to the spectators, especially if the viewers are not capable of discriminating between sources, creating awareness of media literacy should be considered a pressing matter. As stated by Ngafifi (2014), technological development has a tendency to disseminate adverse effects 
in socio-cultural aspects, such as moral degradation among individuals in communities, juvenile delinquency, and changes in interaction patterns. The parental role, therefore, is vital and strategic in this case to raise awareness on media literacy in the families.

However, before carrying out the role, the parents should master essentials understanding of social media. Otherwise, barely will the parents arm themselves with the knowledge that could help them resuscitate their family to use media wisely. Research by Mas' Amah and Hana (2018) showed that media literacy that is conducted by Posyandu attendants in Kupang regency is merely accessing media and evaluating the content while content analysis and message dissemination mostly has not been mastered by them. Similarly, Khoiri (2017) also found that media literacy among older people is not ample, and therefore, affecting their communication behavior on media literacy. It is found that the informants' intelligence on media literacy was still not high. Only two informants that regulated television time limit while the rest three did not make any regulation.

The finding is quite regrettable since one of the functions of the family is fo socialization in which the family becomes the locus of socialization for all members of the family (Latif, 2007; 23). In this vein, socialization that was intended was media literacy in the family. It is advantageous for strongly founding the children and adolescents with proper knowledge before leaving their family and meeting another group in society.

Informants that have regulated television watch-time effectively in their family said that it could work because the family has made a consensus about the issue. Furthermore, it also works because the parents also try to be excellent examples for the children to emulate, and since parents are one of the best role models for the children (Darwadi. MS, 2017; 46), the children will get to grips with the behavior, mainly if the activity is consistently carried out by the parents. As regards habit, it is one of many personal factors that significantly can affect human behavior. It is an aspect of human behavior that is stable, automatic, and unplanned (Rakhmat, 2008: 32). Therefore, if children have been gotten used to watching with proper patter and not excessive, the effect on physical and psychological development will be notable too (Subagijo, 2011: 53).

There are five methods that can be carried out by parents or older people to make their family member more conscious in using media, namely: (1) limit children television time limit; (2) set time to watch television with the children; (3) mute advertisement session as it could get children to be consumptive; (4) arrange children schedule so as to be merely a part of children activity; (2) involve children in formulating the regulation; and (6), after watching the program together, discuss the content that have been viewed (Subagijo, 2011; 108-110).

Furthermore, Khoiri (2017: 698) recommends that parents should explain show in the television to the children and supervise them. Asking the children to switch the channel if there is an inappropriate program, as well as placing a TV in a place that is easy to monitor and limit television time limit, is also preferable. As for the time limit, the American Academy of Pediatrics (AAP) suggests that the ideal time limit for children is 2 hours per day or 14 hours per week (Subagijo, 2011; 110). Also, the type of program should be monitored since it is determined whether the children will consume violence, sex-related content, and swearing words, or not.

Besides television, the research also investigated internet literacy. The research found that there were informants that limit internet use in their houses by giving certain quota for a month for each family member, namely Rp. 20.000. This strategy was performed as it was advantageous in controlling family expenses, and the family did not install a wi-fi facility in the house.

One of the reasons for which the parents should limit internet use is that, like other types of technology, internet bear upside and downside for both children and adolescents (Day and Qodariah, 2018:2). Although, positively, it could help children look for educated games, learn about new technological changes, search innovative learning program, train some parts of the brains, ease communication, and expand networks, internet could also, negatively, as explained by Kurnia (2017), expose radiation so as to put strain on eyes, make children be prone to cyberbullying, lead children to addiction, halt children development both physically and psychologically, and weaken their assimilation process to school subjects.

Furthermore, different from contents on electronic and printed media (Muthmainnah dan Junaedi; 2018), materials on the internet are a combination of printed media and media that prioritize audio and visual elements. As a result, the internet is deemed more thrilling by the users and could provide more suitable content. These changes have children's and adolescents' lives fuse with social and digital media on the internet. This is the reason for which some experts 
recommend that children should be led to use the internet as an informational source for studying and not only for information that is pleasurable and desirable (Darwadi, 2017: 39).

As to internet use, all parents in the research used social media while other family members used internet for not only accessing social media but also playing game and completing task from school or colleges, and, considering that informants' family members regularly access social media, some parent reported that they frequently reminded their family members not to upload improper content in their social media accounts. Mrs. Hos Hori Laga Ndum is one of them, and she said in the interview held on 20 July 2018:

...while, as regards watching television, we have never limited our children to enjoy, for internet use, we frequently rule them out from posting careless posts on their Facebook.

Especially that (activity, namely) sharing risky news that might not be valid. I am worried if the kids get troubles, mam.

Mitigation that has been done by the informants showed that informants have recognized the harmful effects of media use for their families. Indeed, issues in social media by disseminating fake news or hoax have often induced bigotry that is unsuited with Indonesian culture that put tolerance on a pedestal (Juliswara, 2017; 142).

Moreover, regarding other adverse effects upon internet use, informants agreed that internet use could imperil the eye's health, students' understanding of school-subjects, and financial situation. This finding also showed that this response occurred in informants that limited television time limit. Therefore, it can be said that the informants were more concerned about the economic, educational, and health consequences of media rather than harmful content on the internet.

This conclusion affirmed that informants' capability of media literacy was still limited and incomprehensive since literate individuals will be capable of interpreting the meaning behind the media's message and criticize the contents. Potter (2004) contended that media literacy is a tool that is used actively by the audiences to interpret the meaning of the information they encounter while they face media. This finding is relatively regrettable, considering the vital role of parents in sifting the negative consequences of internet use. Parents much appear in introducing appropriate cultural values for children since they are the closest environment. Besides, they also play significant roles in doing the reading and watching culture for their offsprings. Parent's habits indirectly affect children's behavior (Darwadi, 2017;46).

With the above in mind, it can be said that communication behavior, which is defined as communicative action that could be verbal or non verbal that is done by an individual (Kalangi, 2016), of Posyandu's attendants in raising awareness of media literacy in the family was carried out by limiting television time limit and internet use.

\section{Challenges and the Measures in Establishing Understanding of Media Literacy in the Family}

Parents that set a television time limit for the kids cannot consistently execute the rule. They reasoned that rarely can children find entertainment but television. Indeed, the weather was not suitable for kids since it was considerably hot and the wind blowing quite strong. The parents were worried that it may impinge on children's health.

That inconsistency resulted in a high average time spent on consuming TV, although the Indonesian television programs are fairly inimical for children's development. For example, Indonesian Broadcasting Commission (KPI) (2016:179) reported that 91\% of Indonesian television programs were for adult, $97 \%$ of the shows were entertainment show and only $3 \%$ that were educational. Moreover, KPI also asserted that many advertisements were inappropriate due to promoting consumerism and hedonism, engender children be mature before the phase (AFI, Idola Cilik, and etc.), and engender problematic contents, ranging from sex-related materials, violence, swearing words, to mythical program. Not to mention that current television programs hardly consider showtime and many children who were not children-friendly. However, although the parents frequently were inconsistent with limiting time spent for watching television, they still endeavor to tackle the challenges by getting the kids to carry out physical activities at home. Physical activities that typically were conducted were doing chores, including folding shirts and dress or cleaning up the house. The informants also suggest the offsprings study than watch TV. 
Turning to challenges in internet use, mostly the hurdle was parents understanding toward internet technology. While they were expected to be capable of adapting to technological changes since according to media ecology theory technical influence is mostly inescapable and technology will always be a hive of profession and lives (West dan Turner, 2014; 139), the parents seemed confused in deciding which action that should be executed towards the family. As explained before, while older informants typically only accessed social media, such as facebook, WhatsApp, and TikTok, other younger family members had surfed and explored internet facilities regularly, such as searching browsing, downloading, uploading, playing games, and etc. One of the explanation probably is the large discrepancy between generations that emerges because of incapability of accessing various information through digital technology (Hope, Schwaba, dan Piper, 2014; 3903, in Ashari, 2018; 155). This lack of knowledge about the internet is the reason for which modern society's parental guide is necessary for internet use (Leung dan Lee, 2011; 118 in Kurnia, 2017; 9).

In consequence, as the research shown, what informants typically did was reminding the family member not to excessively use the internet because of health consideration that may be harmful for eyes or and limit the quota to cut the family budget although unwise internet use may risk the users with consequence that are wider than economic and health impacts. For example, they may meet with individual who could harm them, be exposed with social deviation and other problematic contents, such as pornography, violence, and bigotry, be connected with pedophilia network, be exploited commercially, and be violated in terms of privacy (Leung dan Lee, 2011: 118 in Kurnia; 2017 ; 10). Furthermore, it is worth considering that according to Adi (2017:8-10) there are four patterns of parental supervision of internet use for their family members, namely mediation (by discussing the content of the internet), introductory (by introducing internet with parental explanation), restriction (by restricting when, how long, and what substances that can be accessed), and co-viewing (by involving children in the activities pertaining with internet use)

Considering the result, it is reasonable to assert that follow up from many competent stakeholders are needed to tackle the challenges in establishing media literacy's understanding in the family and making more societies conscious of the importance of media literacy in this era.

\section{Communication Behavior Model of Posyandu Attendants in Establishing Understanding of Media Literacy in the Family}

Media literacy is a set of skills that are required by all individuals in societies, including parents, which in this case are housewives who work in Posyandu in Oeltua village, Taebenu district, Kupang regency, East Nusa Tenggara. However, according to the finding, media literacy is a term that is strange and foreign for them. Their ignorance of this term makes them not understand the real meaning and the importance of media literacy.

This condition also causes media literacy's ability of Posyandu's attendants that became informants of the research to be not comprehensive. Their capability was limited in accessing and evaluating the content while analysis ability and communicating message was not found. Despite that, some informants have started to conduct communication behavior in their family to be wise in using media. As stated by Buluamang (2018), communication behavior could be observed through their habit of communication so that the communication behavior of individuals could be their habits. The result of communication behavior is an action in which the technique and skill of the actors to attain their communication aim will be demonstrated. That communication techniques will be seen in a verbal or non-verbal way. In light of that, the communication behavior of Posyandu's attendant in their families will be seen in their verbal and nonverbal actions in their families.

Communication behavior that was performed by the informants were limiting television time limit and limit families' quota on internet use. This action was performed verbally and nonverbally. Verbal communication that was executed was by relentlessly reminding the family members no to watch and use internet too long while non-verbal communication was through facial expression and body gestures so that the family members could follow what was delivered by the informants. The research did not found informants that make notes or written rules that can be read by the members. 
On the other hand, finding found that there are challenges in limiting media use. Parents mostly were not consistent with running the rules and had not ample knowledge on the internet. In terms of restricting television time limits, parents were not consistent since there were no other media that provide entertainment, as well as hot and windy weather that may harm the family members to have activities outside. To tackle the problems, the parents asked the family members to assist them in chores and limit internet quota.

Vital points of the research is that parents motive to limit the media use were mainly associated with health motives (that it may harm children eyes), educational purposes (that it may disturb teaching-learning process) and economic reasons (that it may make the book to be not balanced because of too much expense for electricity and internet data) rather than their reservation on harmful effect of mass media if media is not used critically and wise. Consequently, family members, in this case, the children and adolescents were exposed by media with a quite high frequency and were prone to undergo adverse effects of mass media. This situation also contributes to the media literacy ability of informants' family members. The explanation above could be demonstrated through this diagram:

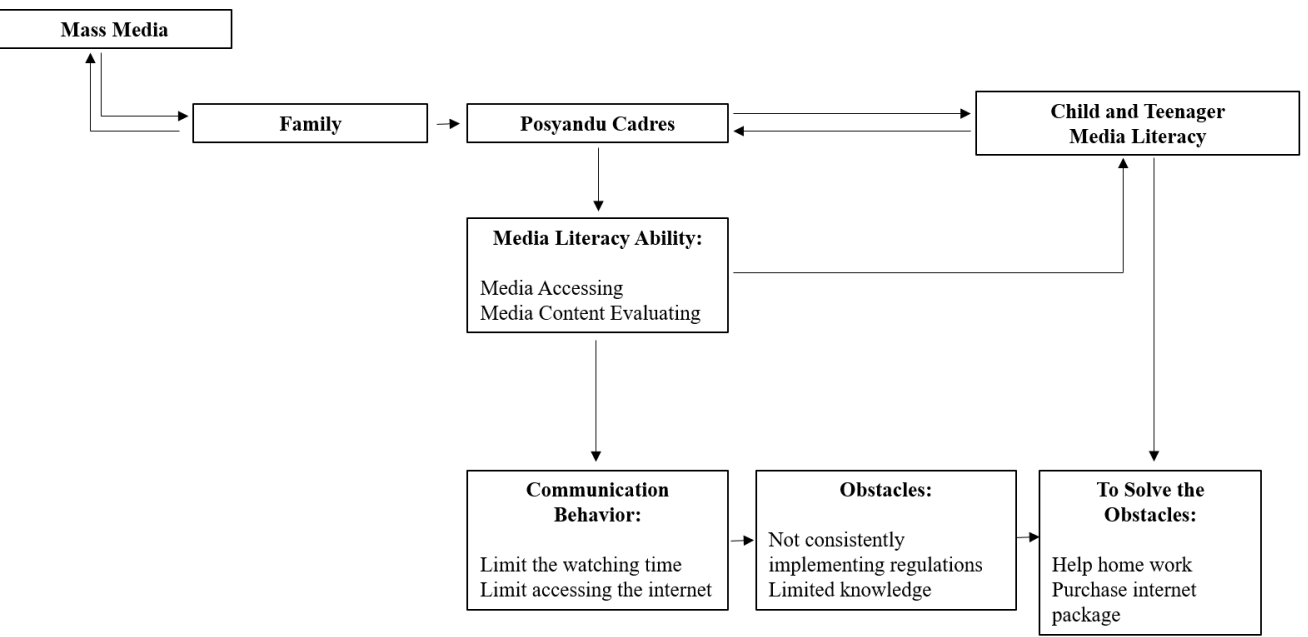

Figure 1. Media Literacy Ability of Informant's Family Members

Source: Researcher, 2018

\section{CONCLUSION}

Living in this age where the world was full of media, media literacy is clearly vital for anyone. Media literacy needs to be groomed from the family as it is the place where values performed to live in society is set. Parents that are also Posyandu attendants in Oeltua village were deemed potential in establishing media literacy in the family as the attendants often participate in workshops and receive a vast amount of information, including social media.

The research has reported a communication behavior model of Posyandu's attendants in establishing an understanding of media literacy in the family. This model has showed that even though media literacy ability of Posyandu's attendant has not comprehensive yet since they only access and evaluate the contents of the media, they have done some efforts to raise awareness of media literacy in the family as their communication behavior, namely by limiting the average time spent in watching television and constraining family members to use internet. These efforts were made verbally and non-verbally.

However, there are some challenges in realizing that aim. The parents were not that consistent in applying the rules of using media and incapability of parents in using the internet entirely. To tackle the problem, the parents tried to involve the children in doing other activities, such as doing chores and limit the quota of internet data. With this in mind, it is clear to say that many stakeholders should be involved to invite society to be more intelligent and critical in using media. 
Furthermore, Posyandu attendants that also figured in being an excellent example of the community should also be strengthened on media literacy. It should not be limited to time in accessing media but also focus on enhancing understanding of discriminating and sifting between information, both for the attendants and the family members.

\section{REFERENCES}

Adi, Tri Nugroho, (2017), Pola Pengawasan Orang Tua Terhadap Aktivitas Anak di Dunia Maya: Studi Kasus Pada Keluarga dengan Anak Remaja Usia 12 - 19 Tahun di Purwokerto. Jurnal Acta Diurna. Vol 13 No. 2 Tahun 2017: 1 - 20.

Adebiyi, A., Akinbode, M., Okuboyejo, S., Agbodola, M.G. Ang Oni, A.A., (2015), Sosial Networking and Students' Academic Performance: The Role of Attention Deficit, Predictors of Behavior and Academic Competence. [online].

Ashari, Rizqi Ganis, (2018), Memahami Hambatan dan Cara Lansia Mempelajari Media Sosial, Jurnal Ilmu Komunikasi. Vol. 15 No. 2, Desember 2018: 155-170.

Buluamang, Yohanes Museng Ola, (2018), Hubungan Antara Perilaku Komunikasi Kepala Daerah dengan Citra Publik dan Ekspektasi Publik, Jurnal Studi Komunikasi dan Media, Vol. 22 No. 1 Juni 2018: 75 - 87.

Croteau, David., dan Hoynes, William, (2000), Media Society: Industries, Images, and Audiences, Edisi Kedua: Pine Forge Press

Darwadi. MS, (2017), Media Baru Sebagai Informasi Budaya Global, Jurnal Komunikator Vol. 9 No. 1 Mei 2017: $39-47$.

Day, Vania Maovangi., dan Qodariah, Siti, (2018), Menumbuhkan Literasi Digital Pada Anak Usia Sekolah 6 - 12 Tahun, Porceeding, unisba.ac.id

Hoobs, Reene, (1999), Acquisition of Media Literacy Skills Among Australian Adolescent, Journal of Broadcasting and Electronic Media, USA.

Juliswara. Vibriza, (2017), Mengembangkan Model Literasi Media yang Berkebinekaan dalam Menganalisis Informasi Palsu (Hoaz) di Media Sosial, Jurnal Pemikiran Sosiologi, Vol. 4 No. 2. 2017: 142 - 164.

Kalangi, Paramitha Amanda Rorimpandey J. S, (2016), Perilaku Komunikasi Pengguna Sosial Media Path (Studi Pada Mahasiswa Ilmu Komunikasi FISIP Universitas Sam Ratulangi), e-journal Acta Diurna Vol. V No. 3 Tahun 2016.

Khoiri. Muhibbul, (2017), Literasi Media Televisi di Kalangan Orang tua di Dukuhan Sanggrahan, Condongcatur, Depok, Sleman, E-Jurnal Prodi Teknologi Pendidikan Vol. VI No. 7 tahun 2017: 1698 - 711. [diakses tanggal 17 Juni 2018].

KPI, (2016), Hasil Survey Indeks Kualitas Program Siaran Televisi Periode 3 tahun 2016, Tidak diterbitkan.

KPID NTT, (2019).

Kurnia, N, (2017), Literasi Digital Keluarga, Yogyakarta: Center For Digital Society (CFDS).

Latif, Abdul, (2007), Pendidikan Berbasis Nilai Kemasyarakatan, Bandung: PT Refika Aditama.

Lawang, Robert M.Z, (1985), Pengantar Sosiologi, Jakarta: Karunia.

Mas'Amah, (2017), Literasi Media Televisi Pada Remaja SMP di Kota Kupang (Studi Kasus Perilaku Menonton Televisi Pada Remaja SMP di Kota Kupang), Disertasi. Tidak diterbitkan.

Mas'Amah., dan Hana, Ferly Tanggu, (2018), Literasi Media Kader Posyandu di desa Oeltua Kecamatan Taebenu Kabupaten Kupang Provinsi Nusa Tenggara Timur. Prosiding, Kupang: Lembaga Penelitian Undana.

Miles, H.B., dan Huberman, A.M, (1994), Qualitative Data Analysis: A sourcebook Of New Methods (Edisi $\mathrm{Ke}-2)$. Thousand Oaks. CA: Sage.

Muthmainnah, Aditsa Amalia., dan Junaedi, Fajar, (2018), Literasi Media Berbasis Media Baru: Aplikasi Model Literasi Media Berbasis Media Baru Oleh remotivi Tahun 2015 - 2018. http://repository.umy.ac.id/bitstream/handle/123456789/21549/JURNAL.pdf?sequence=1 $1 \&$ isAllowed $=\mathrm{y}$.

Ngafifi, M, (2014), Kemajuan Teknologi dan Pola Hidup Manusia Dalam perspektif Sosial Budaya. Jurnal Pembangunan Pendidikan: Fondasi dan Aplikasi [online]. 
Potter, W. James, (2004), Media Literacy: Third Edition, London: Sage Publication.

Rakhmat, Jalaluddin, (2008), Psikologi Komunikasi, Bandung: Remaja Rosdakarya.

Siregar, Syofian, (2013), Statistik Parametrik Untuk Penelitian Kuantitatif: Dilengkapi Dengan Perhitungan Manual dan Aplikasi SPSS Versi 17, Jakarta: Bumi Aksara.

Starsburger, V.C. (2010), Children, Adolescent, and the Media: Seven Keys Issues, Pediatric Annuals. 39: 556-564.

Subagijo, Azimah, (2011), Panduan Sosialisasi Literasi Media televisi: Pegangan Untuk Narasumber; Literasi Media Sebagai Program yang Berkesinambungan, Jakarta: KPI Pusat.

West, R., dan Turner, Lynn H. (2014). Pengantar Teori Komunikasi: Analisis dan Aplikasi, Terjemahan Brian Marswendy. Jakarta: Salemba Humanika.

Yudono, Johdi, (2011), Duh...81 Persen Anak NTT Seharian Nonton Sinetron, Available at: http://nasional.kompas.com/read/2011/11/16/21480647/duh.81.persen.anak.ntt.seharian.n onton.sinetron. 